
performance as affected by the drip irrigation depth and mulching. Horticultura Brasileira 26: 447-451.

\title{
Net melon performance as affected by the drip irrigation depth and mulching
}

\author{
Rodrigo OC Monteiro'; Rubens D Coelho'; Paulo CT de Melo²; Priscylla Ferraz ${ }^{1}$; Sérgio WP Chaves ${ }^{1}$; \\ Fernando H Shirahige ${ }^{2}$; Eugênio Beltrame Neto ${ }^{1}$; Sônia Maria de S Piedade ${ }^{1}$ \\ USP-ESALQ, ${ }^{1}$ Dep ${ }^{\text {to. }}$ Engenharia Agrícola; ${ }^{2}$ Dep $^{\text {to. }}$ Produção Vegetal, C. Postal 09, 13418-900 Piracicaba-SP; ferraz@esalq.usp.br
}

\begin{abstract}
The modern techniques of water supply through irrigation can substantially reduce water waste, which contributes to attend the enlarging water demand. The objective of this work was to study the influence of subsurface drip irrigation and mulching over melon yield and quality characteristics, in a sandy soil (Typic Hapludox). The experimental design was blocks at random, with four replications. Treatments were displayed in a $2 \times 3$ factorial (with and without mulching $x$ surface and 0.20 and 0.40 depth subsurface drip irrigation). Mulching using double-sided silver/black film increased fruit average mass, plant production, yield, daily growth rate for plant height and crown diameter, fruit distal diameter, and pulp thickness. The subsurface drip irrigation at $0.20 \mathrm{~m}$ depth resulted in larger fruit average mass, plant production, and yield than surface and $0.40 \mathrm{~m}$ depth drip irrigation.
\end{abstract}

Keywords: Cucumis melo, drip irrigation system, production, postharvest.

\begin{abstract}
RESUMO
Desempenho do melão rendilhado em função da profundidade de gotejo e utilização de mulching

As atuais técnicas de aplicação de água pelos sistemas de irrigação podem reduzir substancialmente os desperdícios de água, o que contribui para atender a crescente demanda por esse recurso natural. O objetivo deste trabalho foi estudar aspectos produtivos e de qualidade de frutos de melão rendilhado em sistema de gotejo subterrâneo e cobertura plástica (mulching), em solo arenoso (Latossolo Vermelho-Amarelo). O delineamento adotado foi em blocos casualizados, com quatro blocos, com o arranjo dos tratamentos em fatorial 2 x 3 (com e sem mulching x gotejo superficial e subsuperficial, a 0,20 e 0,40 $\mathrm{m}$ de profundidade). O mulching utilizando filme dupla-face prateado/preto incrementou a massa média de fruto, a produção por planta, a produtividade, a taxa de crescimento diário da altura de planta e do diâmetro do colo da planta, o diâmetro longitudinal do fruto e a espessura de polpa. A profundidade de gotejo a 0,20 m resultou em maior massa média de fruto, produção por planta e produtividade quando comparado ao gotejo superficial ou em subsuperfície, a $0,40 \mathrm{~m}$.
\end{abstract}

Palavras-chave: Cucumis melo, irrigação localizada, produção, póscolheita.

(Recebido para publicação em 10 de setembro de 2007; aceito em 17 de outubro de 2008) (Received in September 10, 2007; accepted in October 17, 2008)

$\mathrm{T}$ he mounting demand for water in different activities, mainly in association with the incorporation of new irrigated areas into production, both in Brazil and elsewhere in the world, places into the spot the need for an increasingly rational water management (Bucks, 1995). Due to shortage, either in quantity or in quality, water is no longer a free good, but it turned out to have an economic value. According to ONU/OMS information, as presented by Garcia (2004), there are countries already importing potable water, draining it from glaciers or even trading water by petrol. In this framework, the efficiency in water use became an everyday requirement to all users.

Among the irrigation methods, surface drip irrigation was the one that experienced the fastest development in the last decades due to the rational and economically efficient water use it provides. Several studies show that drip irrigation is effective in applying both water and fertilizers, especially in melon, that does not cope well with humidity in its aboveground part (Sousa et al., 1999; Pinto et al., 1999). An interesting alternative in this context is the subsurface drip irrigation. In addition to the regular advantages of the drip irrigation, supplying water in subsurface reduces losses due to evaporation, reaches directly to the rooting zone, avoids mechanical damages to the pipes due to cultivating procedures and rodents, contributes to a larger root development, reduces humidity in the soil surface, and mitigates disease incidence (Camp, 1998; Silva et al., 1999). Vásquez (2003), when studying surface and subsurface drip fertirrigation in net melon, hybrid Bônus $\mathrm{n}^{\mathrm{o}} \mathrm{II}$, under protected cultivation at Piracicaba, SP, observed commercial and total yield respectively 45 and $63 \%$ higher for subsurface $(0,20 \mathrm{~m}$ depth) in relation to surface drip irrigation. The position of the pipe emitters influenced both $\mathrm{K}^{+}$ concentration and distribution in the melon rooting zone.

The use of plastic films to cover soils, called mulching, is gaining importance in hampering water losses due to evaporation. Mulching may save 5 to $30 \%$ in the amount of water required by plants (Allen et al., 1998). The use of plastic to cover the soil avoids fruit direct contact with ground, positively influencing quality and appearance, and therefore contributing to raise fruit marketable yield and net income. In addition, mulching decreases evaporation at soil surface and play a 
significant role in reducing crop evapotranspiration (Silva, 2002), especially in the initial stages of plant development. Thus, mulching consists in an important option for scaling-down water use in agriculture.

The use of such practices, namely subsurface drip irrigation and mulching, concurs to improve crop quality, especially in melon, which responds well to irrigation. Considering that, the objective in this work was studying yield and quality aspects of melon produced using drip irrigation and mulching, in a sandy soil.

\section{MATERIAL AND METHODS}

The work was carried out at the Rural Engineering Department of the Agriculture College Luiz de Queiroz (ESALQ), São Paulo State University (USP), in Piracicaba, São Paulo State. The experiment was installed in a $20 \mathrm{x}$ $14 \mathrm{~m}$ greenhouse, with $2.5 \mathrm{~m}$ height.

Ground from a Typic Hapludox was used to fill in 1.07 long $x 0.97 \mathrm{~m}$ width x $0.65 \mathrm{~m}$ height boxes. The soil had, in average, $75 \%$ sand, $4 \%$ silt, and $21 \%$ clay (loam sandy textural class), for the layer from 0 to a $0.40 \mathrm{~m}$ deep, and the following physic-chemical characteristics for the layers from 0 to $0.20 \mathrm{~m}$ and from 0.20 to $0.40 \mathrm{~m}$, respectively: $\mathrm{P}=7.0$ and $5.0 \mathrm{mg} \mathrm{dm}^{-3} ; \mathrm{S}$ $=57.0$ and $44.0 \mathrm{mg} \mathrm{dm}^{-3} ; \mathrm{pH}=5.4$ and 5.0; Organic matter $=14$ and $13 \mathrm{~g} \mathrm{dm}^{-3}$; $\mathrm{K}=1.0$ and $0.9 \mathrm{mmol}_{\mathrm{c}} \mathrm{dm}^{-3} ; \mathrm{Ca}=21.0$ and $19.0 \mathrm{mmol}_{\mathrm{c}} \mathrm{dm}^{-3} ; \mathrm{Mg}=10.0$ and $9.0 \mathrm{mmol} \mathrm{dm}^{-3} ; \mathrm{H}+\mathrm{Al}=13.0$ and 18.0 mmol dm ${ }^{-3} ; \mathrm{SB}=32.0$ and $28.9 \mathrm{mmol}^{\circ}$ $\mathrm{dm}^{-3} ; \mathrm{CTC}=45.0$ and $46.9 \mathrm{mg} \mathrm{dm}^{-3}$; soil global density $=1.58$ and $1.43 \mathrm{~g} \mathrm{~cm}^{-3}$; humidity at field capacity $=21.6$ and $27.7 \%$, and humidity at the permanent wilting point $=12.1$ and $18.8 \%$.

Treatments were sorted in a $2 \times 3$ factorial, in complete blocks at random, with four replications and 2-plant plots. Treatments corresponded to presence or absence of plastic film (PP and AP) over the soil and dripping depth (0, 0.20, and $0.40 \mathrm{~m}$ ), being named as follows: $\mathrm{T} 1=$ $\mathrm{AP}$ and $0.0 \mathrm{~cm}$ depth; T2 $=\mathrm{AP}$ and 0.20 $\mathrm{m}$ depth; T3 = AP and $0.40 \mathrm{~m}$ depth; T4 $=\mathrm{PP}$ and $0.0 \mathrm{~cm}$ depth; T5 = PP and 0.20 depth; and T6 = PP and $0.20 \mathrm{~m}$ depth.
The crop used was the net melon (Cucumis melo, L.), hybrid Bônus $\mathrm{n}^{\circ} \mathrm{II}$. Sowing took place in 128-cell Styrofoam trays. Plantlets were transplanted to boxes placed in the greenhouse 21 days later, in November 04, 2005, when presenting two permanent leaves. Each box contained a sole plant, irrigated using an emitter that, according to the specific treatment, could be at the soil level or subsurface (Figure 1). Double-sided mulching (black/silver) 25 micra thick and with light reflection higher than $25 \%$ was used.

Six boxes were picked to install tensiometers in radial distances from the emitter $(0.10,0.20,0.30$, and $0.40 \mathrm{~m}$, for the later only in boxes with plastic film), 0.15, 0.30, and $0.50 \mathrm{~m}$ deep (Figure 1). Therefore, nine tensiometers were placed in the boxes with uncovered soil and 12 in boxes with mulching.

The results of the soil chemical analyses were interpreted as indicated by Raij et al. (1997) and Ribeiro et al. (1999), aiming at recommending liming and fertilization for protected cultivation. Fertilization was supplied weekly through the irrigation water, as suggested by Medeiros \& Maia (2001), according to the crop uptaking rate and soil chemical analysis. Fertilization was calculated to reach yields of 30 to 40 $\mathrm{Mg} \mathrm{ha}^{-1}$, in an 88-day cycle. $\mathrm{N}$ sources were ammonium sulphate $(20 \% \mathrm{~N})$ and urea $(45 \% \mathrm{~N})$, while $\mathrm{P}$ and $\mathrm{K}$ sources were respectively phosphoric acid (55 $\left.\% \mathrm{P}_{2} \mathrm{O}_{5}\right)$ and potassium chloride $(60 \%$ $\mathrm{K})$. Phosphoric acid was supplied alone due to the incompatibility with the other fertilizers, which might have caused precipitation and led to a further blocking of the emitters. Fertilizers were applied using direct suction from a 500L container with constant stirring, where the mixtures were prepared.

Frequent hand-weeding was carried out, keeping the boxes free of competing plants. Agrochemicals, according to the technical recommendation for both products and dosage, were used in preventive control of pests and diseases, against the white-fly, leaf-miner, mildew, and the pickleworm. To guarantee the pollination, as soon as blossoming started and for the following two weeks, a beehive was kept in the center of the structure.

Two harvests were carried out: the first in January 23, 2006 and, the second, three days later, summing up a total cycle of 84 days after transplanting. All harvested fruits were considered for yield assessments, while the aspects related to fruit quality were evaluated over samples. The yield characteristics were: fruit average mass (FM), in $\mathrm{g} \mathrm{fruit}^{-1}$, obtained dividing the total fruit mass by the number of fruits in each experimental plot; plant production (PP), in $\mathrm{g} \mathrm{plant}^{-1}$, obtained by the division of the total fruit mass by the number of plants in the plot (two plants); yield itself (Y), in $\mathrm{Mg} \mathrm{ha}^{-1}$, obtained by the multiplication of PP by the estimate of the number of plants in a hectare; fruit distal (DD) and transversal diameter (TD), obtained by measuring fruit diameter in both directions using a conventional flexible tape-measure; fruit shape (FS) (non-dimensional), corresponding to the ratio between fruit distal and transversal diameters; and fruit skin (ST) and pulp thickness (PT) $(\mathrm{mm})$, assessed using a digital paquimeter.

The characteristics related to fruit quality were content of soluble solids (SS, ${ }^{\circ}$ Brix), determined using drops from the pulp, after homogenizing in a home blender, and assessed in an Auto Abbe rephratometer, model 10500/ 10501 Leica (A.O.A.C., 1992); fruit $\mathrm{pH}$ (non dimensional), measured in liquid samples using a potenciometer Tecnal, according to methodology suggested by A.O.A.C. (1992); fruit titratable acidity (TA), assessed in an 10-g pulp ground aliquot, mixed with $50 \mathrm{~mL}$ of distilled water, titrated with standardized $\mathrm{NaOH}$ $0,01 \mathrm{M}$, using phenol-phthalein $1 \%$ as indicator, and expressed in $\mathrm{g}$ of citric acid in $100 \mathrm{~g}$ of pulp (INSTITUTO ADOLFO LUTZ, 1986); and pulp texture (PT), assessed with the aid of a texturemeter Texture Test System, model TP-1, coupled to an automatic register of strength variation, which was controlled from a standard shear compression cell CS-1, with 10 1/8" thick blades in a $90^{\circ}$ angle. Samples were weighted and placed in the shear compression standard cell, in such a way 
Table 1. Yield characteristics and fruit quality attributes for net melon grown with and without mulching (características de rendimento e atributos de qualidade de frutos de melão rendilhado cultivado com e sem mulching). Piracicaba, USP-ESALQ, 2006.

\begin{tabular}{|c|c|c|c|c|c|c|c|c|c|c|c|c|c|c|c|c|c|c|c|c|c|c|}
\hline & & & & & & $\mathrm{PH}_{29}$ & & & & & $\mathrm{CD}_{29}$ & $\mathrm{CD}_{38}$ & $\mathrm{CD}_{43}$ & & TD & 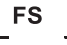 & RT & PT & & pH & TA & \\
\hline & (g) & (kg) & $\left(\mathrm{kg} \mathrm{ha}^{-1}\right)$ & & & $\mathrm{cm} \mathrm{dia}{ }^{-1}$ & & & & & (mm dia & & & & $m$ & & & $\mathrm{~mm}$ & ${ }^{\circ}$ Brix & & g & \\
\hline & & $3.06 \mathrm{a}$ & $30626 a$ & & & & & & & & & & & & & & & & 11.20 & 6,06 & & \\
\hline & $1681 b$ & $3.35 b$ & $3504 b$ & & & $4.08 b$ & & & $0.30 \mathrm{~b}$ & $0.26 \mathrm{~b}$ & $0.26 \mathrm{~b}$ & & $26 b$ & $48.3 \mathrm{t}$ & o $45.6 a$ & 1.06 & 1.32 & & 11.34 & 6,09 & & \\
\hline & & & & & $37^{* *}$ & $185^{* *}$ & $28^{* *}$ & 1.3 & $4.9^{*}$ & $12.3^{* *}$ & $13.2^{* *}$ & $14.5^{* *}$ & $13.6^{* *}$ & $13.6^{*}$ & 4.5 & 2.9 & & $5.9^{*}$ & $.2^{\mathrm{ns}}$ & $0,6^{\text {ns }}$ & & \\
\hline רחה & 4.3 & 0.257 & 571 & 22 & 0.37 & 0.36 & 0.86 & 39 & 0.02 & 0.02 & 0.02 & 002 & 002 & 1.0 & 1.06 & 0.03 & .18 & 2.12 & 0.70 & 0,09 & 0,012 & $\begin{array}{lll}2 & 0,4\end{array}$ \\
\hline$/ 3(\%)$ & & 9.2 & & 3.1 & $\begin{array}{l}122.2 \\
\end{array}$ & 4.0 & 27.5 & 0.5 & 8.3 & 10.0 & 10.8 & 10.4 & 11.2 & 2. & 2.6 & 2.7 & 15.7 & 6.2 & 1.7 & 7,1 & 13,5 & 514,9 \\
\hline
\end{tabular}

Means followed by the same letter in the column did not differ from each other, Tukey test, $\mathrm{p}<0.05^{*}$ or $\mathrm{p}<0.01^{* *}$ (médias seguidas de mesma letra nas colunas não diferem significativamente entre si, teste de Tukey, $\mathrm{p}<0,05^{*}$ ou $\left.\mathrm{p}<0,01^{* *}\right) ;{ }^{1} \mathrm{FM}=$ Fruit mass (massa do fruto); PP = plant production (produção por planta); $\mathrm{Y}=$ yield (produtividade); $\mathrm{PH}=$ daily growth rate for plant height (taxa de crescimento diário da altura das plantas); $\mathrm{CD}=$ daily growth rate for plant crown diameter (taxa de crescimento diário do diâmetro do colo das plantas); DD and $\mathrm{TD}=$ fruit distal and transversal diameter (diâmetros longitudinal e transversal do fruto); FS = fruit shape (formato do fruto); RT and PT = fruit rind and pulp thickness (espessuras da casca e da polpa do fruto); CSS = content of soluble solids (teor de sólidos solúveis); TA = titrable acidity (acidez titulável); FT = fruit texture (textura do fruto); ${ }^{2} \mathrm{LSD}=$ Least significant difference (diferença mínima significativa; ${ }^{3} \mathrm{CV}=$ coefficient of variation (coeficiente de variação).

that blades would act in parallel to the samples. The results given in pounds in the device were converted to Newton $(\mathrm{N}), 1 \mathrm{~N}=4.45 \mathrm{Pd}$.

The morphological evaluation was carried out in all plants, in five dates during the first phase of the plant cycle, namely 6, 23, 29, 38 and 43 days after transplanting (DAT). The following characteristics were assessed: (1) daily growth rate for plant height $(\mathrm{PH})(\mathrm{cm}$ day $^{-1}$ ), obtained by dividing plant height at the evaluation date by the number of growing days. Plant height was assessed from the crown to the main stem apex, using a tape-measure; (2) daily growth rate for crown diameter (CD) (mm day $\left.{ }^{-1}\right)$, obtained dividing the crown diameter at the evaluation date by the number of growing days. The crown diameter was measured using a digital paquimeter, 1 cm over soil level.

The statistical analysis of data was performed using the analysis of variance and the $\mathrm{F}$ test, applied in agreement with the experimental design. Considering that this experiment dealt with qualitative factors (dripping depth and soil plastic mulching), the Tukey test, at $5 \%$ probability, was used to compare treatment means.

\section{RESULTS AND DISCUSSION}

There was no significant interaction between the studied factors for none of the characteristics evaluated. Therefore, results for each factor are presented and discussed individually.
Mulching significantly influenced fruit average mass (FM), plant production $(\mathrm{PP})$, yield $(\mathrm{Y})$, daily growth rate for plant height $(\mathrm{PH}) 23,29$, and 38 days after transplanting (DAT), daily growth rate for crown diameter (CD) in all evaluation dates, fruit distal diameter, and pulp thickness (Table 1). According to some researchers (Sganzerla, 1997; Hochmuth et al., 2001; Sanders, 2001), carrot, cucumber, eggplant, garlic and onion, lettuce, melon and watermelon, pepper and sweet pepper, okra, squash and pumpkin, strawberry, tomato, and water-cress are vegetables that benefit from the use of plastic films as soil mulching.

Mulching increased FM in $150 \mathrm{~g}$ in average (Table 1) when compared to results obtained in uncovered soil. The increment is considerable, once it represents an estimate of additional 3 $\mathrm{Mg} \mathrm{ha}^{-1}$ in crop yield, when the useful area for each plant and the adopted crop system are taken into account. Similar values were found by Costa (2003), using a silver polyethylene plastic cover in a soil with loam clayey texture. Andrade (2001), Miranda et al. (2003), Araújo et al. (2000), and Ferreira et al. (2001a), who worked with black polyethylene plastic, also found significant differences in FM between mulching and uncovered soils.

The average values for PP and Y (Table 1) indicate that mulching induced an increment of approximately $10 \%$ over the results observed for the uncovered soil. Negreiros et al. (2003), when comparing uncovered and covered soil, using black, silver, yellow, and brown plastic films as mulching, for Cantaloupe melon grown in Mossoró, Rio Grande do Norte State, noticed that the highest yields for both total and marketable fruits came from the treatments where mulching was employed.

The daily growth rate for plant height $(\mathrm{PH})$ was determined upon the variation of average plant height in time during the first half of the plant cycle (vegetative phase). At the evaluation performed 16 DAT, there was no significant influence of mulching over $\mathrm{PH}$, probably because plants were still too small to any effect to be noticed. The average values show that mulching raised $\mathrm{PH}$ in at least $77 \%$ when compared to uncovered soil. Mulching effects are likely to be related to the higher soil temperature and to silver plastic capacity to reflect solar radiation, which might have allowed bottom and inner leaves to benefit from the reflected radiation. Consequently, the photosynthetic active area in the plant was enlarged and more photosynthesis products were available for plant development, as postulated by Tsekleev et al. (1993). Andrade (2001) also found significantly higher $\mathrm{PH}$ values associated to the use of mulching in comparison to uncovered soil.

The average values of $\mathrm{CD}$ (Table 1) show that the smallest difference between plants grown with and without mulching, in average 7\%, for both soil 
Table 2. Yield characteristics and fruit quality attributes for net melon grown in surface and 0.20 and 0.40 subsurface drip irrigation (característica de rendimento e atributos de qualidade de frutos de melão rendilhado cultivado com gotejamento superficial e subsuperficial, a 0,20 e 0,40 m). Piracicaba, USP-ESALQ, 2006.

\begin{tabular}{|c|c|c|c|c|c|c|c|c|c|c|c|c|c|c|c|c|c|c|c|c|c|c|}
\hline & \multirow{2}{*}{$\begin{array}{l}F^{1}{ }^{1} \\
(g)\end{array}$} & \multirow{2}{*}{$\begin{array}{l}P P^{1} \\
\text { (kg) }\end{array}$} & \multirow{2}{*}{ 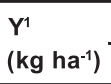 } & $\mathrm{PH}^{1}{ }_{16}$ & $\mathrm{PH}_{23}$ & $\mathrm{PH}_{29}$ & $\mathrm{PH}_{38}$ & $\mathrm{PH}_{43}$ & $\mathrm{CD}^{1}{ }_{16}$ & $C D_{23}$ & $C D_{29}$ & $C_{38}$ & $\mathrm{CD}_{43}$ & DD & TD & \multirow[t]{2}{*}{ FS } & RT & PT & \multirow{2}{*}{$\begin{array}{l}\text { CSS } \\
-{ }^{\circ} \text { Brix }\end{array}$} & \multirow{2}{*}{$\mathrm{pH}$} & \multirow{2}{*}{$\begin{array}{l}\text { TA } \\
\mathrm{g}\end{array}$} & \multirow{2}{*}{$\begin{array}{l}\mathbf{P T} \\
\mathbf{N}\end{array}$} \\
\hline & & & & \multicolumn{5}{|c|}{$(\mathrm{cm} \mathrm{dia-1})$} & \multicolumn{5}{|c|}{$\left(\mathrm{mm} \mathrm{dia}^{-1}\right)$} & \multicolumn{2}{|c|}{$\mathrm{cm}$} & & \multicolumn{2}{|c|}{$\mathrm{mm}$} & & & & \\
\hline Mulching & PO & $1526 a$ & $3.05 a$ & $30520 a$ & 1.13 & 1.98 & 2.99 & 3.64 & & 0.30 & 0.26 & 0.25 & 0.23 & 0.24 & 47.1 & & 1.05 & 1.45 & 39.3 & 11,31 & 6,1 & 0,097 \\
\hline Uncovered & $\mathrm{P} 20$ & $1712 b$ & $3.44 b$ & $34361 b$ & 1.05 & 1.79 & 2.78 & 3.50 & 4.52 & 0.29 & 0.24 & 0.24 & 0.22 & 0.24 & 47.8 & 45.1 & 11.06 & 1.23 & 39.1 & 111,13 & 6,05 & 0,110 \\
\hline F test & P40 & $1581 \mathrm{ab}$ & $3.13 a b$ & $31315 a b$ & 1.07 & 1.95 & 3.04 & 3.07 & 4.40 & 0.28 & 0.23 & 0.23 & 0.22 & 0.23 & 47.2 & & 1.04 & 1.28 & 39.7 & & 6,06 & 0,101 \\
\hline $\mathrm{LSD}^{2}$ & Teste F & $3.6^{*}$ & $3.8^{*}$ & $3.8^{*}$ & $0.2^{\text {ns }}$ & $0.5^{\mathrm{ns}}$ & $0.9^{\text {ns }}$ & $0.7^{\mathrm{ns}}$ & $3.0^{\text {ns }}$ & $1.8^{\mathrm{ns}}$ & $2.1^{\mathrm{ns}}$ & $1.1^{\mathrm{ns}}$ & $1.1^{\mathrm{ns}}$ & $0.5^{\mathrm{ns}}$ & $0.7^{\mathrm{ns}}$ & $0.5^{\text {ns }}$ & $1.3^{\text {ns }}$ & $2.5^{\mathrm{ns}}$ & $0.1^{\mathrm{ns}}$ & $0,2^{\text {ns }}$ & $0,9^{\text {ns }}$ & $1,9^{\text {ns }}$ \\
\hline \multirow[t]{2}{*}{ CV3 (\%) } & DMS & 185.7 & 0.383 & 3839 & 0.32 & 0.55 & 0.54 & 1.28 & 0.58 & 0.03 & 0.03 & 0.03 & 0.03 & 0.03 & 1.61 & 11.58 & 0.03 & 0.27 & 3.17 & 1,05 & 0,13 & 0,018 \\
\hline & $\mathrm{CV}$ & 8.9 & 9.2 & 9.2 & 23.1 & 22.2 & 14.0 & 27.5 & 10.5 & 8.3 & 10.0 & 10.8 & 10.4 & 11.2 & 2.1 & 2.6 & 2.7 & 15.7 & 6.2 & 1,7 & 7,1 & 13,5 \\
\hline
\end{tabular}

Means followed by the same letter in the column did not differ from each other, Tukey test, $\mathrm{p}<0.05^{*}$ or $\mathrm{p}<0.01^{* *}$ (médias seguidas de mesma letra nas colunas não diferem significativamente entre si, teste de Tukey, $\mathrm{p}<0,05^{*}$ ou $\left.\mathrm{p}<0,01^{* *}\right) ;{ }^{1} \mathrm{FM}=$ Fruit mass (massa do fruto); $\mathrm{PP}=$ plant production (produção por planta); $\mathrm{Y}=$ yield (produtividade); $\mathrm{PH}=$ daily growth rate for plant height (taxa de crescimento diário da altura das plantas); $\mathrm{CD}=$ daily growth rate for plant crown diameter (taxa de crescimento diário do diâmetro do colo das plantas); DD and $\mathrm{TD}=$ fruit distal and transversal diameter (diâmetros longitudinal e transversal do fruto); FS = fruit shape (formato do fruto); RT and PT = fruit rind and pulp thickness (espessuras da casca e da polpa do fruto); CSS = content of soluble solids (teor de sólidos solúveis); TA = titrable acidity (acidez titulável); FT = fruit texture (textura do fruto); ${ }^{2} \mathrm{LSD}=$ Least significant difference (diferença mínima significativa; ${ }^{3} \mathrm{CV}=$ coefficient of variation (coeficiente de variação).

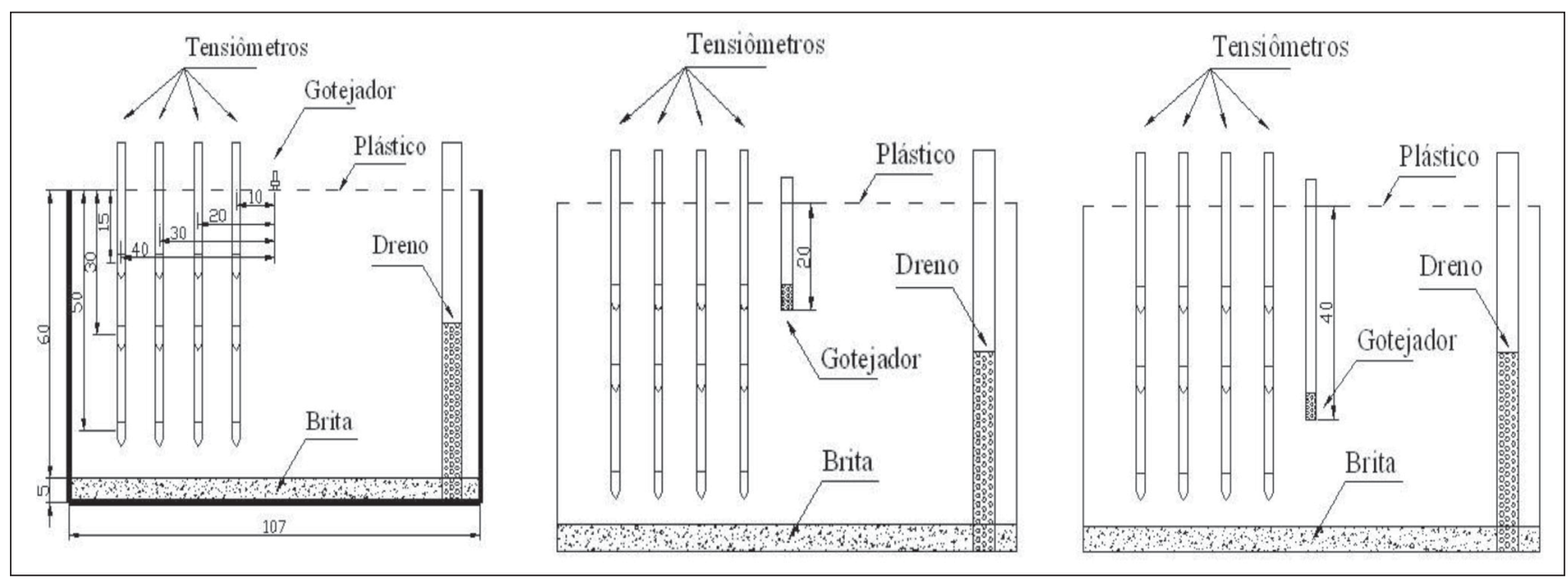

Figure 1. Layout of the superficial and subsuperficial $(0.20$ and $0.40 \mathrm{~m})$ placing of the drip emitters and tensiometers in the boxes (posicionamento superficial e subsuperficial $(0,20$ e $0,40 \mathrm{~m})$ do gotejador e disposição dos tensiômetros nas caixas). Piracicaba, USPESALQ, 2006.

categories, was found 16 DAT. Just as mentioned above for $\mathrm{PH}$, it is likely that this evaluation was too early to observe the mulching influence in comparison to uncovered soil. In the remaining evaluation dates $(23,29,38$, and 43 DAT), an average difference of $17.4 \%$ was observed in favor of plants grown with mulching in comparison to those grow in uncovered soil.

Mulching resulted in a $4 \%$ increase in fruit distal diameter (DD). Andrade (2001) did not find significant effects of covering the soil over DD and fruit transversal diameter (TD). In the present work, values for fruit shape (FS) ranged, in average, from 1.04 to 1.06 , which corresponds to a spherical shape. There was no mulching influence over FS.

Mulching significantly influenced pulp thickness (PT), producing an increase of $2.5 \mathrm{~mm}$. Andrade (2001) however did not find significant effects of mulching over PT. Costa (2003) observed that, although fruits produced out of treatments with mulching using black, silver, and brow polyethylene had statistically similar PT when compared to each other, they all exceeded the results observed for fruits produced without mulching. Gondim et al. (2003) reported that PT was larger in fruits produced using mulching than in fruits grown on bare soil.
When considered individually, mulching and dripping depth did not significantly influence any of the fruit quality characteristics studied herein. Araújo et al. (2000) and Ferreira et al. (2001a,b) did not find significant differences among treatments for fruit quality traits (total soluble solids and pulp firmness) in yellow melon, cultivar Gold Mine, when the soil was left uncovered or covered with either black or silver polyethylene film or ground wax-palm straw. On the other hand, Brandenberg \& Wiedenfeld (1997) observed an increment of $0.6 \%$ in the content of soluble solids for treatments with film in comparison to uncovered 
soil. Maiero et al. (1987), upon studying several Cantaloupe melon genotypes grown with soil mulching in Maryland (USA), found that, regarding soluble solids, the influence of transparent and black plastic films did not significantly differ from each other, yielding an average content of 9.2 and $9.0^{\circ} \mathrm{Brix}$, respectively, although both treatments exceeded in $10 \%$ the content of soluble solids in fruits grown in uncovered soil.

Dripping depth significantly influenced fruit average mass (FM), plant production (PP), and yield (Y) (Table 2). The largest FM was achieved when water was dripped at $0.20 \mathrm{~m}$ depth. Vásquez (2003) found similar results with pipe emitters placed at the subsurface $(0.20 \mathrm{~m})$, which induced larger FM values than surface dripping. $\mathrm{PP}$ and $\mathrm{Y}$ increased approximately $13 \%$ when water was applied through dripping at $0.20 \mathrm{~m}$ depth in relation to surface dripping. Vásquez (2003) also found higher PP and Y values (45\%) for pipe emitters placed in subsurface $(0,20 \mathrm{~m})$ than for surface dripping.

The use of double-sided silver/black plastic film as soil mulching increased fruit average mass, plant production and yield, daily growth rate for plant height and crown diameter, fruit distal diameter, and pulp thickness. Dripping water at $0.20 \mathrm{~m}$ depth raised fruit average mass, plant production, and yield, when compared to surface dripping and $0.40 \mathrm{~m}$ depth.

\section{ACKNOWLEGMENTS}

To the National Council for Scientific and Technological Development $(\mathrm{CNPq})$, for funding this work.

\section{REFERENCES}

ALLEN RG; PEREIRA LS; RAES D; SMITH M. 1998. Crop evapotranspiration: guidelines for computing crop water requirements. Roma: FAO. 328p. (Irrigation and Drainage Paper, $56)$.
ANDRADE JWS. 2001. Cultivo de híbridos de melão, com e sem cobertura do solo, em estufas cobertas com filmes de polietileno com diferentes características ópticas. Ilha Solteira: UNESP. 75p. (Tese mestrado).

AOAC. 1992. Official methods of analysis of the Association of Analytical Chemists International. Washington: A.O.A.C. 1141p.

ARAÚJO AP; NEGREIROS MZ; NETO FB; PEDROSA JF; FERREIRA R LF. 2000. Cobertura do solo e métodos de plantio na produção de melão. Horticultura Brasileira 18, suplemento: 517-518.

BRANDENBERGER L; WIENDENFELD B. 1997. Physical characteristics of mulches and their impact on crop response and profitability in muskmelon production. HortTechnology 7 : 165-169.

BUCKS DA. 1995. Historical development in microirrigation. In: INTERNATIONAL MICROIRRIGATION CONGRESS, 5. Anais... Orlando: Proceedings. p. 1-5.

CAMP CR. 1998. Subsurface drip irrigation: a review. Transactions of the ASAE 41: 1353-1367.

COSTA FA. 2003. Coberturas do solo e lâminas de irrigação no rendimento e qualidade do melão 'Gold Mine' cultivado no período chuvoso. Mossoró: ESAM. 63p. (Tese mestrado).

FERREIRA RLF; NEGREIROS MZ; LEITÃO MMVBR; PEDROSA JF; BEZERRA NETO F; ESPÍNDOLA SOBRINHO J; COELHO JKS; LIRA GS. 2001a. Rendimento do melão 'Gold Mine' em diferentes coberturas de solo e métodos de plantio. Horticultura Brasileira 19, suplemento: 283-284.

FERREIRA RLF; NEGREIROS MZ; LEITÃO MMVBR; PEDROSA JF; BEZERRA NETO F; ESPÍNDOLA SOBRINHO J; COELHO JKS; LIRA GS. 2001b. Qualidade do melão 'Gold Mine' em diferentes coberturas de solo e métodos de plantio. Horticultura Brasileira 19, suplemento: 285-286.

GARCIA AR. 2004. Amazônia: planeta água. In: CONGRESSO INTERNACIONAL DE DIREITO AMAZÔNICO, 1. Anais... Boa Vista: ABDA. p. 20-36.

GONDIM ARO; PORTO DRQ; NEGREIROS MZN; MENEZES JB; MEDEIROS JF; COSTAFB; SENHOR RF; BEZERRA NETO F. 2003. Armazenamento sob atmosfera modificada de melão Cantaloupe 'Torreon' cultivados em diferentes tipos de cobertura de solo e lâminas de irrigação. Horticultura Brasileira 21: 123-126.

HOCHMUTH GJ; HOCHMUTH RC; OLSON SM. 2001. Polyethylene mulching for early vegetable production in North Florida. Disponível em http:/ /edis.ifas.ufl.edu/BODY_CV213. Acessado em 22 de fevereiro de 2006.

INSTITUTO ADOLFO LUTZ. 1986. Normas Analíticas do Instituto Adolfo Lutz. São Paulo: IAL. 533p.
MAIERO M; SCHALES FD; NG JT. 1987. Genotypeand plast mulch effects on earliness, fruit characteristics, and yield in muskmelon. HortScience 22: 945-46.

MEDEIROS JF; MAIA CE. 2001. Manejo da fertirrigação. Mossoró: ESAM. 16p. (Apostila).

MIRANDA NO; MEDEIROS JF; NASCIMENTO IB; ALVES LP. 2003. Produtividade e qualidade de frutos de melão em resposta à cobertura do solo com plástico preto e ao preparo do solo. Horticultura Brasileira 21: 490-493.

NEGREIROS MZ; COSTA FB; MENEZES JB; MEDEIROS JF; BEZERRA NETO F; LEITÃO MMVBR; PORTO DRQ; GONDIM ARO; SALDANHA TRFC. 2003. Horticultura Brasileira 21, suplemento: 308.

PINTO JM, BOTREL TA, MACHADO EC, FEITOSA FILHO JC, MEDINA CL. 1999. Aplicação de $\mathrm{CO}_{2}$ via água de irrigação na cultura do melão em ambiente protegido. Revista Brasileira de Engenharia Agrícola 18: 1-10.

RAIJ B; CANTARELLA H; QUAGGIO JA; FURLANI AMC. 1997. Recomendações de adubação e calagem para o Estado de São Paulo. Campinas: IAC. 285p. (Boletim Técnico, 100).

RIBEIRO AC; GUIMARÃES PTG; ALVAREZ VVH (Ed.). 1999. Recomendações para o uso de corretivos e fertilizantes em Minas Gerais. Viçosa: Comissão de Fertilidade do Solo do Estado de Minas Gerais. 359p.

SANDERS DC. 2001. Using plastic mulches and drip irrigation for vegetable production. Disponível em http://www.ces.ncsu.edu/depts/ hort/hil-33.html. Acessado em 23 de fevereiro de 2006.

SGANZERLA E. 1997. Nova agricultura: a fascinante arte de cultivar com os plásticos. Guaíba: Agropecuária. 342p.

SILVA MCC. 2002. Crescimento, produtividade $e$ qualidade de frutos do meloeiro sob diferentes níveis de salinidade da água de irrigação e cobertura do solo. Mossoró: ESAM. 65p. (Tese mestrado).

SILVA WLC.; GIORDANO LB.; MAROUELLI WA; FONTES RR; GORNAT B. 1999. Response of six processing tomatoes cultivars to subsurface drip fertigation. Acta Horticulturae 487: 569-573.

SOUSA VF; RODRIGUES BHN; ATHAYDE SOBRINHO C; COELHO EF; VIANA FMP; SILVA PHS. 1999. Cultivo do meloeiro sob fertirrigação por gotejamento no meio-norte do Brasil. Teresina: Embrapa Meio-Norte. 68p. (Circular Técnica, 21).

TSEKLEEV G; BOYADJIEVAN; SOLAKOV Y; TABAKOVA M. 1993. Influence of photoselective mulch films on tomates in greenhouses. Plasticulture 95: 45-49.

VÁSQUEZ MAN. 2003. Fertirrigação por gotejamento superficial e subsuperficial no meloeiro (Cucumis melo L.) sob condições protegidas. Piracicaba: ESALQ/USP. 145p. (Tese doutorado). 